\author{
PÓRHILDUR ODDSDÓTTIR \\ HÁSKÓLA ÍsLANDS
}

\title{
Um Caju Rude
}

Á 1929 kom út í Danmörku smásagnasafnið Skyggebilleder fyrsta bók höfundarins, en á næstu fjórtán árum sendi hún frá sér tíu skáldverk til viðbótar. Hún samdi einnig tvö leikrit á árunum 19251926 sem tekin voru til sýninga á landsbyggðinni. Nú eru verk Caju Rude lítt pekkt og nafn hennar nánast gleymt, en styrkur hennar sem höfundar var ódrepandi áhugi á samfélagslegum málefnum. Hún bar hag hinna veiku og fátæku fyrir brjósti og tókst að lýsa peim slæmu kjörum sem persónur hennar máttu búa við í anda raunsæisstefnunnar.

Æska Caju Rude var stormasöm. Hún fæddist í Frederiksberg 11. júlí 1884 og ólst upp í Frederikshavn og Randers. Faðir hennar yfirgaf móðurina og átta börn árið 1892, sem leiddi meðal annars til pess að fjölskyldan tilheyrði ekki lengur borgarastéttinni. Svo virðist sem Caja Rude hafi aðeins haft tveggja ára skólagöngu að baki pegar hún varð að fara að vinna sökum fátæktar. Hún giftist 23 ára en hjónabandið entist aðeins í örfá ár. Pann tíma bjuggu hjónin í bænum Stege og síðan Korsør. Strax pá skipaði Rude sér í forystusveit réttindabaráttu kvenna. Einnig lét hún sig miklu skipta efnalegan ójöfnuð í samfélaginu allt til dauðadags 1949.

Caja Rude hóf ritferil sinn með greinum í blöð og tímarit árið 1910, en sama ár og Skyggebilleder kom út var hún fastráðin við SocialDemokraten, flokksblað jafnaðarmanna, og málefni kvenna urðu sérsvið hennar. Hún var árum saman ritstjóri pósthólfsins Spørg Villa, par sem hún svaraði spurningum um (sam)félagsleg vandamál og kom bréfriturum í samband við stofnanir og samtök sem veittu fé- 
lagslega eða fjárhagslega aðstoð. Efnistök hennar sem blaðamaður og rithöfundur sköruðust töluvert og í bókum sínum fjallaði hún um pólitíska baráttu í samtímanum og var undir áhrifum frá hugsjónum jafnaðarmanna, par sem mikið var rætt um menningu fátækra heimila, hlutverk og kjör kvenna. Konur höfðu í orði kveðnu náð jafnrétti við karla á ýmsum sviðum á fyrsta hluta 20. aldar. Umræða um eðli pessara breytinga var mikil á priðja og fjórða áratugnum, ekki síst deilur um siðferði, móðurhlutverk og fjölskylduform. Meiri menntun og aukin sjálfsvirðing var talin bæta stöðu kvenna í baráttu peirra fyrir betri félagslegum og fjárhagslegum kjörum.

Á árunum 1930-1939 skrifaði Rude sjö skáldsögur, sem einkum voru ætlaðar ungum stúlkum og segja má að hafi verið drjúgt innlegg í pessa umræðu. Hún varð einna fyrst rithöfunda til að sýna kvenpersónur sínar á annan hátt en í hinu hefðbundna húsmóðurhlutverki. Í fyrstu verkum hennar voru aðalpersónurnar ungar konur sem urðu fyrir árásum, valdníðslu og niðurlægingu, en smám saman fóru að birtast myndir af óttalausum og sterkum stúlkum. Pessar bækur eru proskasögur, pó fyrst og fremst í peim skilningi að söguhetjan fræðir hinn unga lesanda með pví að sýna styrk og skapfestu gagnvart peim hættum sem ógna ungu fólki, sem gat verið allt frá pví að vera undirborgað og misnotað á vinnumarkaði að ótímabærum pungunum, áfengisneyslu og lausung. Barátta ungra stúlkna fyrir menntun og atvinnu var í fyrirrúmi í sî̉ari verkunum og börðust söguhetjurnar jafnvel fyrir pví að fá að læra hefðbundin karlastörf, s.s. múrverk og að stunda nám í bændaskóla. Caja Rude aðhylltist opnari umræðu um kynfræðslu og var talsmaður pess að innleiða slíka fræðslu í skólum. Fyrsta bókin af pessum sjö vakti sérstaka athygli vegna opinskárrar umfjöllunar um kynhvöt og kynlíf, sem og skort á fræðslu handa ungmennum til að leiða pau í gegnum fyrstu kynnin af ástinni.

Skáldsögur Rude fyrir fullorðna voru byggðar á sama grunni en par var pjóðfélagsmyndin víkkuð út og persónur voru fulltrúar smáborgara- og borgarastéttanna. Að hluta til byggði hún par á eigin reynslu eftir að hafa unnið sem hjálparstúlka og sîðar vinnukona á heimilum betri borgara frá tíu ára aldri og kynnst par prældómi og lært margt um félagslega neyð, stéttaskiptingu og kynferðislega misnotkun. Smásagan „Heimsókn“ („Et besøg“) er eitt verkanna í bók- 
inni Skyggebilleder. Í sögunni er dregin upp mynd af ríkri frú sem veit lítið um staðreyndir lífsins en kynni hennar af blásnauðri fjölskyldu gjörbreyta heimsmynd hennar. 